\title{
Pengaruh Faktor Sosial Ekonomi Terhadap Angka Kematian Bayi (AKB) Pada Kabupaten/Kota di Propinsi Jawa Timur
}

\author{
Fadjar Suhaeri $^{*}$, Lilik Sugiharti ${ }^{2}$ \\ ${ }^{1,2}$ Program Studi Magister Ilmu Ekonomi, Fakultas Ekonomi dan Bisnis, Universitas Airlangga \\ Jl. Airlangga N0. 4 Surabaya 60286 Indonesia \\ *e-mail : cakmanager@gmail.com
}

\begin{abstract}
ABSTRAK
Artikel Info

Angka Kematian Bayi (AKB) adalah salah satu indikator

Received :

11 December 2019

Revised :

09 Juni 2020

Accepted :

27 Juni 2020 pembangunan kesehatan. AKB Provinsi Jawa Timur menunjukkan keberhasilannya menurunkan AKB, namun bila diperhatikan pada masing-masing kabupaten kota di provinsi Jawa Timur masih terdapat kesenjangan yang tinggi, selain itu masih terdapat 21 kabupaten kota yang masih diatas target RPJMD 2014-2019 Provinsi Jawa Timur. Penelitian ini bertujuan untuk menganalisis pengaruh faktor sosial ekonomi terhadap Angka Kematian Bayi di Provinsi Jawa Timur. Penelitian ini menggunakan regresi data panel, dengan menggunakan data panel 38 kabupaten kota di Jawa Timur. Penelitian ini menggunakan variabel bebas antara lain : PDRB perkapita, rata-rata lama sekolah pada perempuan, lamanya pemberian ASI, presentase rumah tangga yang waktu tempuh ke fasilitas layanan kesehatan lebih dari 30 menit, jumlah layanan posyandu, jumlah tenaga medis, jumlah tenaga paramedis dan cakupan imunisasi. Hasil uji regresi menunjukkan bahwa seluruh variabel secara simultan berpengaruh terhadap Angka Kematian Bayi di Provinsi Jawa Timur, namun secara parsial hanya variabel lamanya pemberian ASI dan jumlah tenaga medis yang tidak berpengaruh terhadap Angka Kematian Bayi di Provinsi Jawa Timur.
\end{abstract}

Kata kunci : Angka Kematian Bayi (AKB), PDRB perkapita, Imunisasi

\section{Effect of Socio-Economic Factors On Infant Mortality Rate (IMR) In Regencies/Cities In East Java Province}

ABSTRACT

Infant Mortality Rate (IMR) is one indicator of health development. IMR of East Java Province showed its success in reducing IMR, but if considered in each regency in East Java province was still among the high, in addition there were still 21 municipal regencies that still exceeded the 2014-2019 RPJMD target of East Java Province. This study tries to analyze the socioeconomic factors of the Infant Mortality Rate in East Java Province. This study uses a panel data regression, using panel data 38 city districts in East 
Java. This study uses independent variables: PDRB per capita, Mean Years School of Women, length of time supporting breastfeeding, percentage of households that require up to 30 minutes, number of posyandu, number of medical personnel, number of paramedics and immunization. The results of the regression test showed that the overall variable was the infant mortality rate in East Java Province, but only the variables gave breastfeeding and the number of medical workers who did not match the infant mortality rate in East Java Province.

Keywords : Infant Mortality Rate (IMR), PDRB percapita, immunization

\section{PENDAHULUAN}

Keberhasilan Pembangunan Kesehatan dapat diukur salah satunya dengan Indikator Angka Kematian Bayi (AKB). Menurut Rosicova et al (2011), AKB adalah salah satu indikator yang penting dari tingkat kesehatan umum, kesejahteraan masyarakat, pembangunan lingkungan dan sosial ekonomi. AKB tidak hanya mengenai masalah kesehatan bayi tersebut yang menyebabkan kematian bayi, tetapi juga kesehatan ibu, kondisi kesehatan lingkungan dan secara umum tingkat perkembangan sosial ekonomi masyarakat (Mantra, 2015:100).

Indikator Pembangunan kesehatan Indonesia masih harus diperbaiki khususnya angka kematian bayi (AKB). AKB di Indonesia telah mengalami kemajuan yang signifikan dalam upaya penurunan kematian bayi dalam beberapa dekade terakhir. Pada tahun 1960 , AKB di Indonesia adalah 128 per 1.000 kelahiran hidup, angka ini turun menjadi 68 per 1.000 kelahiran hidup pada tahun 1989, hingga pada tahun 2000, AKB telah menurun menjadi 48 per 1.000 kelahiran hidup (BPS). Keberhasilan ini berlanjut hingga pada tahun 2017, data terakhir dari world bank menyatakan bahwa angka kematian bayi di Indonesia mencapai 22 per 1.000 kelahiran hidup. Walaupun telah begitu menggembirakan, tingkat kematian bayi di Indonesia masih tergolong tinggi, jika dibandingkan dengan negaranegara anggota ASEAN, yaitu AKB di Indonesia 1,3 kali lebih tinggi dari Vietnam; 2,4 kali lebih tinggi dari Brunai Darussalam; dan dibandingkan dengan Thailand sebesar 2,6 kali lebih tinggi, serta dengan Malaysia sebesar 3,2 kali lebih tinggi. Bahkan jauh dibandingkan dengan Singapura mencapai 9,7 kali lebih tinggi.

Capaian Angka Kematian Bayi (AKB) dari masing-masing Provinsi di Indonesia juga masih terdapat kesenjangan. AKB terendah di Provinsi DI Yogyakarta sebesar 12,52 jiwa per 1000 kelahiran dan AKB tertinggi di Provinsi Sulawesi Barat sebesar 50,02 jiwa per 1000 kelahiran. Pada tahun 2016, AKB di Indonesia, masih terdapat 24 Provinsi yang masih di atas target RPJMN 2015-2019 yaitu sebesar 24 jiwa per 1000 kelahiran. Khusus pada Provinsi Jawa Timur, capaian AKB sudah dibawah target RPJMN 2015-2019 yaitu sebesar 23,6 jiwa per 1000 kelahiran, namun masih diatas target RPJMD Provinsi Jawa Timur 2015-2019. Target RPJMD Provinsi Jawa Timur 2015-2019 sebesar 22,12 jiwa per 1.000 kelahiran.

Selanjutnya, Angka Kematian Bayi (AKB) di Jawa Timur juga menunjukkan capaian yang menggembirakan, namun masih memerlukan perbaikan. AKB di Jawa Timur menunjukkan trend yang menurun dari 2010 hingga 2016. Pada tahun 2010, angka kematian bayi di Jawa Timur sebesar 29,99 jiwa per 1000 kelahiran, turun menjadi 23,6 jiwa per 1000 kelahiran pada tahun 2016. Pada tahun 2016, Provinsi Jawa Timur telah 
mencapai target RPJMN 2015-2019. Target Angka Kematian Bayi per 1.000 kelahiran hidup pada RPJMN adalah 24 jiwa. Namun, bila diperhatikan pada masing-masing kabupaten kota di provinsi Jawa Timur, masih terdapat kesenjangan yang tinggi antar kabupaten/kota. Kabupaten Probolinggo mempunyai AKB yang tertinggi yaitu 56 jiwa per 1.000 kelahiran hidup, dan kota Blitar mempunyai AKB yang terendah yaitu 15 jiwa per 1.000 kelahiran hidup. Walaupun telah begitu menggembirakan, tingkat kematian bayi di Jawa Timur masih tergolong tinggi, dimana masih terdapat 21 kabupaten kota di Provinsi Jawa Timur yang di atas target RPJMD 2014-2019 Provinsi Jawa Timur. Target Angka Kematian Bayi di Jawa Timur hingga 2019 menurut RPJMD adalah 22,12 jiwa per 1.000 kelahiran hidup.

Provinsi Jawa Timur dapat dikatakan semakin makmur setiap tahunnya. PDRB perkapita sering digunakan sebagai tolak ukur rata-rata standar hidup masyarakat (Blanchard and Johnson, 2013: 208). Semakin besar PDRB perkapita, berarti semakin makmur suatu wilayah tersebut. PDRB perkapita Jawa Timur meningkat dari tahun 2010 sebesar Rp 26.371,1 Juta menjadi Rp 35.962,3 Juta pada tahun 2016. Atau meningkat sebesar 36,37 persen. PDRB perkapita tertinggi terjadi di kota Kediri yaitu Rp 379,19 Juta, diikuti kota Surabaya sebesar Rp. 157,73 Juta, kabupaten Gresik sebesar Rp 84.9 Juta dan Terendah adalah kabupaten Pamekasan sebesar 11.491,2 Juta.

Pendapatan perkapita Provinsi Jawa Timur menunjukkan trend positif seharusnya diikuti oleh angka kematian bayi yang menurun. Namun, seperti apa yang telah dialami negara sedang berkembang, provinsi Jawa Timur dihadapkan dengan kesenjangan distribusi pendapatan, ketimpangan kualitas manusia dan ketimpangan fasilitas kesehatan. Beberapa teori menjelaskan bahwa angka kematian bayi berhubungan erat dengan kondisi perekonomian suatu wilayah. Salah satunya yaitu teori Modernisasi berpendapat bahwa industrialisasi meningkatkan kesejahteraan manusia dan mengurangi kematian bayi (Rostow, 1960:17). Hal ini terjadi karena pertumbuhan ekonomi mendorong peningkatan dalam pendidikan, perumahan, gizi, perawatan kesehatan, sanitasi dan berbagai layanan publik yang mengurangi kematian bayi.

Beberapa kerangka analitis digunakan untuk mempelajari faktor penentu kelangsungan hidup anak. Pada kerangka analitis Mosley dan Chen (1984) membagi variabel yang berpengaruh terhadap kelangsungan hidup anak menjadi dua, yaitu variabel yang eksogen dan variabel endogen. Variabel eksogen adalah variabel seperti sosial, ekonomi masyarakat, serta budaya. Variabel endogen adalah faktor seperti kebersihan, sanitasi, pemberian ASI dan nutrisi. Selanjutnya pada Filmer (2003), tingkat kematian anak dipengaruhi karakteristik rumah tangga (individu) seperti tindakan pencegahan penyakit, pendapatan, pendidikan, dan pengetahuan orang tua atau disebut faktor permintaan. Sedangkan kebijakan pemerintah, kemampuan dari pemerintah daerah, dan infrastruktur serta akses dan kualitas layanan kesehatan disebut sebagai faktor penawaran.

Berlandaskan latar belakang masalah yang telah dipaparkan, penelitian ini bertujuan untuk menganalisis pengaruh faktor sosial ekonomi terhadap angka kematian bayi di Provinsi Jawa Timur. Penelitian ini menggunakan data panel 38 kabupaten kota di Jawa Timur, selama tahun 2010 sampai 2016. Penelitian ini menggunakan variabel bebas antara lain, PDRB perkapita, rata-rata lama sekolah pada perempuan, lamanya pemberian ASI, presentase rumah tangga yang waktu tempuhnya lebih dari 30 menit ke fasilitas layanan kesehatan, jumlah layanan posyandu, jumlah tenaga medis, jumlah tenaga paramedis, dan cakupan imunisasi. Penelitian ini dilakukan, dikarenakan masih tingginya angka kematian bayi di beberapa kabupaten kota pada provinsi Jawa Timur. 


\section{KAJIAN TEORI}

\section{Teori Mosley dan Chen}

Mosley dan chen (1984) membagi variabel yang berpengaruh terhadap kematian bayi menjadi dua, yaitu variabel eksogen dan variabel endogen. Variabel eksogen seperti sosial, ekonomi masyarakat dan faktor budaya. Variabel endogen seperti sanitasi, kebersihan, pola pemberian ASI, dan nutrisi. Hubungan antara kematian bayi dengan faktor eksogen sangat kuat, walaupun masih terdapat hal-hal yang tidak bisa dijelaskan dengan mekanisme langsung. Faktor eksogen merupakan faktor penentu mortalitas secara tidak langsung. Mortalitas merupakan serangkaian mekanisme biologi yang kemudian baru menimbulkan resiko kesakitan bayi dan selanjutnya apabila tidak sembuh, menyebabkan cacat atau meninggal. Kematian bayi merupakan hasil akhir dari perjalanan kumulatif dari berbagai pengalaman kesakitan bayi.

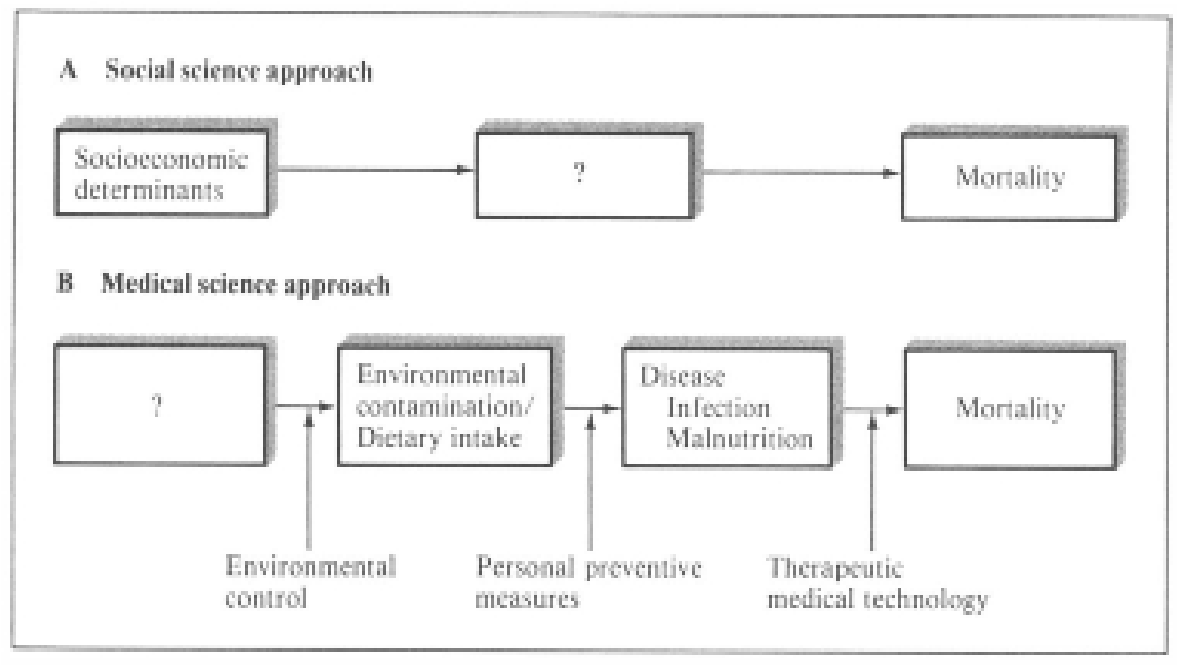

Sumber: Mosley dan Chen (1984)

Gambar 1. Konsep Model Penelitian Sosial dan Penelitian Medis untuk Meneliti Kelangsungan Hidup Anak (bayi)

Penelitian faktor sosial ekonomi dan penelitian faktor medis berhubungan dengan kematian bayi, dapat digambarkan pada gambar 1. Keduanya memberikan kontribusi yang besar bagi pemahaman mengenai penyebab kematian bayi. Kunci dari model kelangsungan hidup anak (bayi) terdapat pada identifikasi sekumpulan variabel yang menyebabkan peningkatan probabilitas kematian pada anak (bayi). Determinan sosial ekonomi dikelompokkan ke dalam tiga kategori umum, yaitu:

a. Variabel tingkat individu.

Variabel tingkat individu meliputi keterampilan atau pendidikan, dan waktu. Tingkat pendidikan dapat mempengaruhi kematian bayi dengan cara mempengaruhi pilihan pelayanan kesehatan dan keterampilan orang tua dalam upaya perawatan kesehatan bayi. Tingkat kesehatan bayi dipengaruhi oleh ketersediaan waktu untuk memberikan ASI, dan melakukan pemeriksaan prenatal. Masyarakat umum cenderung memaksimalkan waktu ibu untuk mengasuh anak/bayi. Namun kenyataannya dalam beberapa kasus, waktu mengasuh anak/bayi sering digunakan untuk bekerja. Sehingga konsekuensinya kesehatan dan kematian bayi menjadi tergantung pada kondisi ekonomi rumah tangga. 


\section{EKONOMIKAWAN : Jurnal Ilmu Ekonomi dan Studi Pembangunan}

I55N : $1693-7600$ (print), 155N : 2598-0157 (Onlire), hutp://umal.umsu.acid//ndex.php/ekawan

b. Variabel tingkat rumah tangga.

Variabel tingkat rumah tangga meliputi kekayaan dan pendapatan. Pengaruh kekayaan dan pendapatan akan mempengaruhi kematian bayi melalui variabel antara. Kekayaan dan pendapatan akan menjamin makanan bergizi, jumlah dan kualitas air, ketersediaan pakaian, ventilasi yang baik, akses ke rumah sakit atau dalam arti lain kekayaan akan menciptakan hidup layak.

c. Variabel tingkat masyarakat.

Variabel tingkat masyarakat meliputi lingkungan ekologi dan kebijakan pemerintah khususnya pada sistem kesehatan. Lingkungan ekologi seperti iklim, curah hujan, temperatur, dan musim berpengaruh terhadap ketersediaan makanan dan ketersediaan pekerjaan. Kebijakan pemerintah meliputi prasarana fisik seperti ketersediaan listrik, jalan raya, hingga rumah sakit dan puskesmas, serta sistem kesehatan. Sistem kesehatan mempengaruhi model tindakan kesehatan yang dilembagakan, subsidi biaya perawatan kesehatan, penyediaan sosialisasi kesehatan.

\section{Teori Filmer}

Dalam teori Filmer (2003), tingkat kematian bayi dipengaruhi oleh Faktor permintaan dan Faktor penawaran. Teori filmer dapat digambarkan pada gambar 2, yang menggambarkan faktor-faktor penyebab capaian kesehatan. Faktor permintaan meliputi karakteristik rumah tangga dan individu seperti pendapatan, pendidikan, pengetahuan orang tua dan sanitasi. Semakin baik pendapatan, pendidikan, pengetahuan orang tua serta semakin baik sanitasi, maka semakin baik tindakan preventif kesehatan, sehingga semakin rendah kematian bayi. Sedangkan dari faktor penawaran, yang menjadi faktor penyebab kematian bayi adalah kebijakan pemerintah. Peran kebijakan pemerintah dapat menjamin akses dan kualitas layanan kesehatan terutama untuk masyarakat miskin, sehingga tingkat kematian bayi dan kasus gizi buruk pada bayi dapat diturunkan.

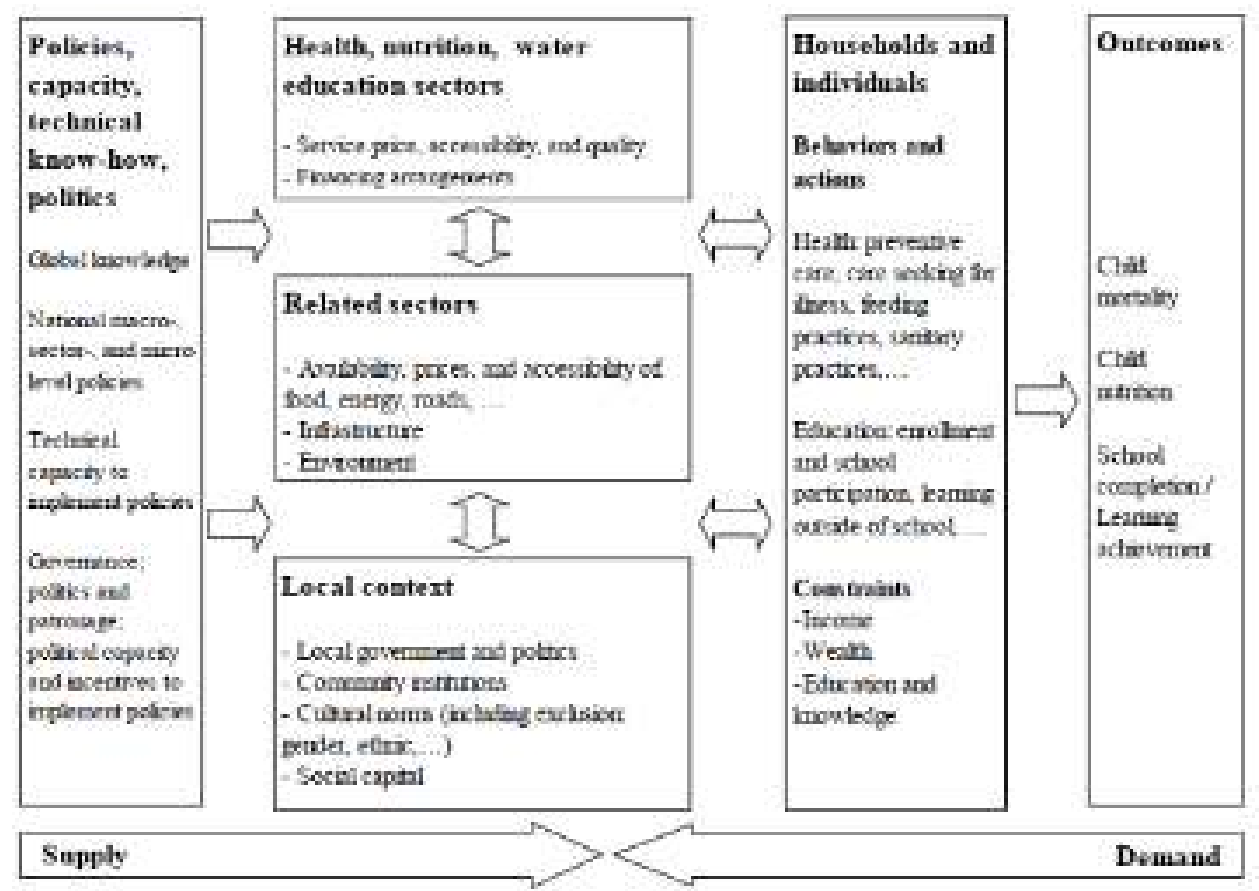

Sumber: Filmer, 2003.

Gambar 2. Determinan permintaan dan penawaran beroperasi melalui banyak saluran 


\section{Penelitian Sebelumnya}

Angka kematian bayi menjadi isu di negara sedang berkembang. Pemerintah banyak melakukan berbagai kebijakan untuk menekan angka kematian bayi. Namun, pengambil kebijakan yaitu pemerintah membutuhkan pengetahuan mengenai strategi menurunkan kematian bayi dan menanggulangi penyakit anak/bayi. Pengetahuan tidak hanya soal medis yang berhubungan langsung dengan kematian bayi, namun hal-hal yang menjadi faktor sosial ekonomi juga berpengaruh terhadap kematian bayi.

Banyak penelitian berkesimpulan bahwa penurunan angka kematian bayi akan tercapai jika memfokuskan perhatian pada program pengurangan ketimpangan pendapatan dan menambah infastruktur sosial. Pada penelitian Bappenas (2009) menghasilkan kesimpulan bahwa faktor kebijakan pemerintah atau faktor penawaran menurut teori Filmer lebih banyak mempengaruhi dalam menentukan kelangsungan hidup bayi. Peran pemerintah dalam menyediahkan layanan kesehatan meliputi jumlah dokter, jumlah tenaga kesehatan, jumlah posyandu. Beberapa penelitian lainnya menyatakan hal yang serupa, bahwa pelayanan kesehatan menentukan kelangsungan hidup bayi antara lain penelitian Warsita dan Marhaeni (2015), Penelitian Danawi dan Ogbonna (2014), Penelitian Abdiana (2015), Kurniawati (2015), dan Jain (1985). Pada pelayanan kesehatan khususnya pada penyediaan tenaga medis dan tenaga paramedis mempengaruhi penurunan angka kematian bayi pada penelitian Nguyen et al (2016) dan Penelitian Anand (2004). Pada penelitian Vaidean dan Pipas (2015) menyatakan bahwa infrastruktur pada penyediaan jumlah tempat tidur rumah sakit mempengaruhi angka kematian bayi. Faktor jarak ke fasilitas kesehatan juga mempengaruhi angka kematian bayi telah diungkapkan pada penelitiannya Pramono (2012).

Peran pemerintah yang lainnya adalah pengeluaran pemerintah pada sektor kesehatan dan penyediaan imunisasi lengkap menentukan angka kematian bayi. Pengeluaran publik memiliki efek negatif dan signifikan terhadap kematian bayi. Beberapa penelitian yang menyatakan hal tersebut antara lain Vaidean dan Pipas (2015), dan Penelitian Rezaei et al (2015). Beberapa penelitian berkesimpulan bahwa faktor pemerintah dalam penyediaan imunisasi lengkap memiliki efek negatif dan signifikan terhadap kematian bayi, antara lain kurniawati (2015), Penelitian Breiman (2004), dan Penelitian Pramono (2012).

Peran pemerintah dalam menyediahkan pemukiman yang sehat juga mempengaruhi angka kematian bayi. Pemukiman padat menciptakan akumulasi kerugian sosial ekonomi terhadap angka kematian bayi. Penelitian Rosicova et al (2011) dan Penelitian Sadetskaya (2015) berkesimpulan yang sama bahwa peningkatan kepadatan perumahan menciptakan kondisi yang tidak menguntungkan untuk peluang kelangsungan hidup bayi.

Selain faktor penawaran atau faktor kebijakan pemerintah, faktor permintaan juga mempengaruhi penurunan angka kematian bayi. Faktor permintaan meliputi karakteristik rumahtangga dan individu seperti pendidikan, pengetahuan orang tua, pendapatan mempengaruhi tindakan pencegahan penyakit. Beberapa peneliti memfokuskan perhatian pada ketimpangan pendapatan. PDRB perkapita digunakan oleh peneliti sebagai proksi pendapatan.

Beberapa peneliti berkesimpulan sama bahwa pendapatan berpengaruh negatif signifikan terhadap angka kematian bayi walaupun pengaruhnya tidak terlalu besar. Beberapa penelitian tersebut antara Warsita dan Marhaeni (2015), Danawi dan Ogbonna (2014), Hulya dan Arik (2009), Nishiyama (2011), Goza et al (2004), Rodgers (2002), Dallolio et al (2012), Kurniawati (2015), Hajarisman et al (2016), Barbus (2011), Flegg (1982), Rezaei et al (2015), dan Sadetskaya (2015). Beberapa peneliti tersebut berpendapatan bahwa pendapatan yang lebih tinggi merupakan prasyarat untuk 


\section{EKONOMIKAWAN : Jurnal Ilmu Ekonomi dan Studi Pembangunan}

I55N : $1693-7600$ (Print), 155N : $2598-0157$ (Online), hutp://Jumal.umstiac.id//ndex.php/ekawan

mendapatkan lingkungan dan makanan yang lebih sehat, serta pelayanan kesehatan yang lebih baik.

Faktor lainnya yang menentukan angka kematian bayi adalah pendidikan. Semakin tinggi pendidikan orang tua semakin banyak pengetahuan, wawasan dan keterampilan yang digunakan untuk merawat bayi mereka. Variabel pendidikan yang digunakan sebagai proksi adalah rata-rata lama sekolah. Beberapa penelitian berpendapat rata-rata lama sekolah orang tua dan kerabat berpengaruh negatif signifikan terhadap angka kematian bayi. Beberapa penelitian tersebut antara lain Hajarisman et al (2016), Nishiyama (2011), Kurniawati (2015) dan Rezaei et al (2015). Namun ada beberapa penelitian secara langsung menggunakan variabel rata-rata lama sekolah pada perempuan yang mempengaruhi angka kematian bayi. Beberapa penelitian tersebut antara lain, Warsita dan Marhaeni (2015), Iram dan Butt (2008), dan Breiman (2004). Pada penelitian Jain (1985) menggunakan angka melek huruf pada perempuan mempengaruhi angka kematian bayi.

Faktor berikutnya adalah waktu yang disediahkan ibu untuk memberikan ASI. Pemberian ASI Eksklusif dipandang sebagai imunisasi alami. Semakin lama rata-rata pemberian ASI semakin rendah angka kematian bayi. Beberapa penelitian berkesimpulan bahwa pemberian ASI berpengaruh negatif signifikan terhadap angka kematian bayi. Beberapa penelitian tersebut antara lain, Iram dan Butt (2008) dan Abdiana (2015).

Penelitian ini mengadopsi variabel-variabel yang digunakan pada penelitian sebelumnya. Variabel yang digunakan adalah PDRB perkapita, rata-rata lama sekolah, lamanya pemberian ASI, waktu tempuh ke fasilitas pelayanan kesehatan, jumlah layanan posyandu, jumlah tenaga medis, jumlah tenaga paramedis, dan cakupan imunisasi. Perbedaan dengan penelitian sebelumnya adalah penelitian ini menggunakan variabel makro dikarenakan lebih bersifat sistemik dan bersifat general dalam melihat persoalan angka kematian bayi.

\section{METODE}

Metode yang digunakan dalam penelitian ini menggunakan regresi data panel. Penelitian ini menggunakan data tahunan periode 2010 sampai dengan 2016 dari 38 kabupaten/kota di Jawa Timur. Data yang digunakan diambil dari data sekunder yang bersumber dari Badan Pusat Statistik (BPS), BPS Provinsi Jawa Timur, Dinas Kesehatan Provinsi Jawa Timur, dan Badan Penelitian dan Pengembangan Kesehatan Kementerian Kesehatan RI. Data-data yang diambil diolah menggunakan software Eviews.

Pada penelitian ini, variabel yang digunakan terdiri dari satu variabel terikat atau dependen dan lima variabel bebas atau independen. Variabel terikat (dependent variable) adalah variabel yang dipengaruhi oleh variabel bebas. Sedangkan, variabel bebas (independent variable) adalah variabel dapat mempengaruhi perubahan dalam variabel terikat dan mempunyai hubungan bagi variabel terikat nantinya. Variabel dependen adalah Angka Kematian Bayi (Y) dan variabel independen yang digunakan adalah PDRB Perkapita (X1), rata-rata lama sekolah pada perempuan (X2), rata-rata lama pemberian ASI (X3), presentase rumah tangga yang waktu tempuhnya kurang dari 30 menit ke fasilitas pelayanan kesehatan (X4), jumlah Posyandu (X5), jumlah tenaga kerja medis (X6), jumlah tenaga kerja paramedis (X7), dan cakupan Imunisasi (X8). Model yang dihasilkan sebagai berikut:

$\mathrm{Y}_{\text {it }}=\beta_{0}+\beta_{1} \mathrm{X} 1_{\text {it }}+\beta_{2} \mathrm{X} 2_{\text {it }}+\beta_{3} \mathrm{X} 3_{\text {it }}+\beta_{4} \mathrm{X} 4_{\text {it }}+\beta_{5} \mathrm{X} 5_{\text {it }}+\beta_{6} \mathrm{X} 6_{\text {it }}+\beta_{7} \mathrm{X} 7_{\text {it }}+\beta_{8} \mathrm{X} 8_{\text {it }}$ zit $\ldots . . . . . .(2.1)$

Keterangan:

Y : Angka kematian Bayi

Copyright@ 02020 , Ekonomikawan : Jurnal IImu ekonomi dan Studi Pembangunan. This is an open access article under the 


\section{EKONOMIKAWAN : Jurnal Ilmu Ekonomi dan Studi Pembangunan}

I55N : $1693-7600$ (Print), 155N : 2598-0157 (Online), hutp:/humal.umsu.ac.id//ndex,php/ekawan

X1 : PDRB Perkapita

X2 : Rata-Rata Lama Sekolah Perempuan

X3 : Rata-rata lamanya pemberian ASI

X4 : Waktu tempuh ke fasilitas pelayanan kesehatan

X5 : Jumlah Posyandu

$\mathrm{X} 6$ : Jumlah tenaga medis

X7 : Jumlah tenaga paramedis

X8 : Cakupan Imunisasi

\section{HASIL DAN PEMBAHASAN}

\section{Kondisi Angka Kematian Bayi di Provinsi Jawa Timur}

Angka kematian bayi (AKB) sangat sensitif terhadap perubahan tingkat kesehatan dan kesejahteraan. Oleh karenanya AKB menjadi indikator yang penting dalam menentukan tingkat kesehatan masyarakat. Pada gambar 3 terlihat bahwa AKB tertinggi pada kabupaten Probolinggo sebesar 56,13, artinya bahwa di kabupaten Probolinggo terdapat $56-57$ bayi yang meninggal pada setiap 1000 kelahiran hidup, sedangkan urutan kedua adalah kabupaten Jember sebesar 50,19, dan urutan terbesar ketiga adalah kabupaten Bangkalan sebesar 48,9.

Gambar 3 juga memperlihatkan suatu hal yang menarik yaitu AKB terbesar terdapat di wilayah Madura dan wilayah Pandalungan. AKB terbesar terdapat di kabupaten Probolinggo. Sepuluh AKB terbesar lainnya terdapat di kabupaten Jember, kabupaten Bangkalan, kabupaten Situbondo, kabupaten Bondowoso, kabupaten Pasuruan, kabupaten Sumenep, kabupaten Sampang, kabupaten Pemekasan, dan kabupaten Bojonegoro. Wilayah Madura dan wilayah Pandalungan mempunyai karakteristik masyarakat yang hampir sama, dimana wilayah pandalungan disebut sebagai tanah tumpah darah kedua bagi masyarakat Madura.

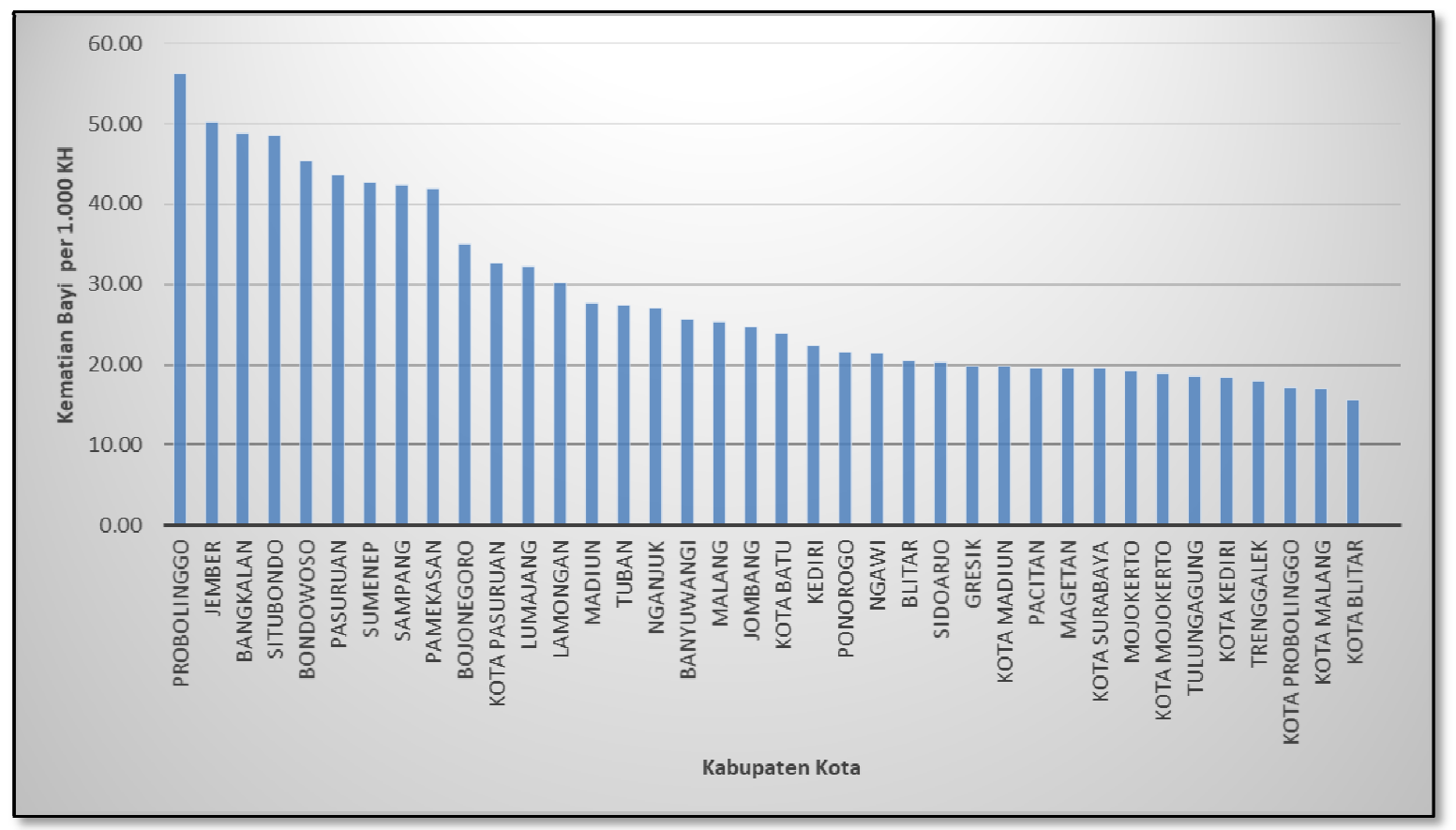

Sumber: BPS Provinsi Jawa Timur, diakses di : jatim.bps.go.id.

Gambar 3. Angka Kematian Bayi (AKB) di Provinsi Jawa Timur tahun 2016 


\section{Regresi Data Panel}

\section{Pemilihan Model Estimasi Data Panel}

Model Estimasi Data Panel menggunakan tiga pendekatan yaitu Ordinary Least Square (OLS) atau Common Effect Model (CEM), Fixed Effect Model (FEM), dan Random Effect Model (REM). Pada Pendekatan Ordinary Least Square (OLS) atau Common Effect Model, mengestimasi data panel hanya dengan menggabungkan data time series dan crosssection tanpa melihat perbedaan antar waktu dan individu. Pendekatan Fixed Effect Model (FEM) merupakan pendekatan untuk mengestimasi data panel yang dapat dibedakan berdasarkan individu dan waktu. Teknik model Fixed Effect mengestimasi data panel dengan menggunakan variabel dummy untuk menjelaskan perbedaan intersep tersebut. Pendekatan Random Effect Model (REM) mengestimasi data panel dengan melibatkan korelasi error term karena berubahnya waktu maupun individu. Pemilihan model estimasi data panel memiliki tiga cara antara lain melalui uji F-statistik (uji Chow Test), Uji Hausman dan Uji Lagrange Multiplier (LM).

\section{Uji Chow}

Uji Chow Test atau uji F-Statistik adalah pengujian yang dilakukan untuk memilih antara Common Effect Model (CEM) atau Fixed Effect Model (FEM) untuk mengestimasi data panel. Uji Chow dengan hipotesis dan kriteria yaitu:

$\mathrm{H}_{\mathrm{o}} \quad$ : Model OLS

$\mathrm{H}_{1}$ : Model FEM

Jika nilai probabilitas lebih besar dari $\alpha$ (prob $>\alpha$ ) maka hipotesis $\mathrm{H}_{\mathrm{o}}$ tidak ditolak. Hal ini berarti teknik estimasi yang digunakan adalah model OLS. Jika probabilitas lebih kecil dari $\alpha($ prob $<\alpha)$ maka hipotesis $\mathrm{H}_{0}$ ditolak. Hal ini berarti teknik estimasi yang digunakan adalah model FE. Pada tabel 1 terlihat bahwa nilai Prob F-Statistik sebesar 0.0000. Hal ini berarti pendekatan Fixed Effect Model (FEM) dipilih, dikarenakan nilai probabilitas lebih kecil dari $\alpha$.

Tabel 1. Uji Chow

\begin{tabular}{|lll|}
\hline $\begin{array}{l}\text { Redundant Fixed Effects Tests } \\
\text { Pool: PANEL } \\
\text { Test cross-section fixed effects }\end{array}$ & & \\
\hline \hline Effects Test & Statistic $\quad$ d.f. & Prob. \\
\hline \hline Cross-section F & $146.767790(37,220)$ & 0.0000 \\
Cross-section Chi-square & 863.39757037 & 0.0000 \\
\hline \hline
\end{tabular}

Sumber : Hasil olah Eviews.

\section{Uji Hausman}

Uji Hausman adalah pengujian untuk memilih model terbaik antara FEM dan REM. Uji ini diperoleh dengan membandingkan nilai probabilitas chi-square dengan $\alpha(1 \%, 5 \%$ atau $10 \%)$. Jika nilai probabilitas kurang dari $\alpha(1 \%, 5 \%$ atau $10 \%)$ maka $\mathrm{H}_{0}$ ditolak sehingga model yang digunakan adalah FEM dan juga sebaliknya. Uji ini menggunakan hipotesis sebagai berikut:

$\mathrm{H}_{\mathrm{o}} \quad$ : Model REM

$\mathrm{H}_{1} \quad$ : Model FEM 
Tabel 2. Uji Hausman

\begin{tabular}{|llll|}
\hline Correlated Random Effects - Hausman Test & & \\
Pool: PANEL \\
Test cross-section random effects & & & \\
\hline \hline & $\begin{array}{l}\text { Chi-Sq. } \\
\text { Statistic }\end{array}$ & Chi-Sq. d.f. & Prob. \\
\hline Test Summary & 23.357021 & 8 & 0.0029 \\
\hline \hline Cross-section random & & & \\
\hline \hline
\end{tabular}

Sumber : Hasil olah Eviews

Pada tabel 2 terlihat nilai Prob sebesar 0.0029. Hal ini berarti pendekatan Fixed Effect Model (FEM) dipilih, dikarenakan nilai probabilitas lebih kecil dari $\alpha$. Hasil uji Hausman yang tetap memilih pendekatan FEM sebagai model estimasi data panel menjadikan uji Lagrange Multiplier (LM) tidak diperlukan lagi untuk dilakukan.

\section{Estimasi model dengan menggunakan pendekatan Fixed Effect Model (FEM)}

Hasil regresi data panel menggunakan pendekatan FEM terangkum pada tabel 3 Slope koefisien variabel PDRB perkapita, rata-rata lama sekolah perempuan, lama pemberian ASI, jumlah posyandu, jumlah tenaga medis, jumlah tenaga paramedis, dan cakupan imunisasi bernilai negatif. Sedangkan, variabel waktu tempuh ke fasilitas layanan kesehatan yang hanya bernilai positif. Nilai $R$ Squared yang termasuk uji Goodness Of fit sebesar 0.985305 .

Tabel 3. Hasil Regresi Data Panel

\begin{tabular}{|l|l|l|l|l|}
\hline Variable & Coefficient & Std. Error & t-Statistic & Prob. \\
\hline $\mathrm{X}_{1}$ (PDRB Perkapita) & -0.00009 & 0.0000276 & -3.264887 & 0.001 \\
\hline $\begin{array}{l}\mathrm{X}_{2} \text { (Rata-rata lama Sekolah } \\
\text { Perempuan) }\end{array}$ & $-2.49 \mathrm{E}+00$ & $4.65 \mathrm{E}-01$ & -5.355816 & 0.000 \\
\hline $\mathrm{X}_{3}$ (Lama pemberian ASI) & -0.266765 & 0.178096 & -1.497869 & 0.136 \\
\hline $\begin{array}{l}\mathrm{X}_{4} \text { (Prosentase RT yang waktu } \\
\text { tempuhnya 30 menit ke fasilitas } \\
\text { layanan kesehatan) }\end{array}$ & 0.146034 & 0.030384 & 4.806345 & 0.000 \\
\hline $\mathrm{X}_{5}$ (Jumlah posyandu) & -0.019895 & 0.007748 & -2.567923 & 0.011 \\
\hline $\mathrm{X}_{6}$ (Jumlah tenaga medis) & -9.474698 & 64.71612 & -0.146404 & 0.884 \\
\hline $\mathrm{X}_{7}$ (Jumlah paramedis) & -56.32352 & 7.11903 & -7.911685 & 0.000 \\
\hline $\mathrm{X}_{8}$ (Cakupan Imunisasi) & -0.016731 & 0.006904 & -2.423471 & 0.016 \\
\hline $\begin{array}{l}\text { Total pool (balanced) observations: } \\
\text { 266 Sig }\end{array}$ & $\begin{array}{l}\text { F } \\
\text { Catatan : * } \text { signifikansi di 10\% }\end{array}$ & \multicolumn{5}{|l}{ R Squared $=0.985305$} \\
\hline
\end{tabular}

Sumber : Hasil olah Eviews

Keseluruhan variabel independen secara bersama-sama berpengaruh terhadap Angka Kematian Bayi. Namun Secara parsial hanya variabel PDRB Perkapita $\left(\mathrm{X}_{1}\right)$, ratarata lama sekolah perempuan $\left(\mathrm{X}_{2}\right)$, waktu tempuh ke fasilitas pelayanan kesehatan $\left(\mathrm{X}_{4}\right)$, Jumlah posyandu $\left(\mathrm{X}_{5}\right)$, variabel tenaga paramedis $\left(\mathrm{X}_{7}\right)$ dan cakupan imunisasi yang berpengaruh terhadap Angka Kematian Bayi. Analisis tersebut berdasarkan signifikasi 10 
persen. Estimasi Model Regresi Data Panel dengan pendekatan FEM membentuk model sebagai berikut :

$$
\begin{aligned}
\mathrm{AKB}= & 78,9-0,00009 \mathrm{X}_{1}-2,4 \mathrm{X}_{2}-0,26 \mathrm{X}_{3}+0,14 \mathrm{X}_{4}-0,019 \mathrm{X}_{5}-9,4 \mathrm{X}_{6}-56,3 \mathrm{X}_{7}-0,01 \\
& \mathrm{X}_{8}+\mathrm{e}
\end{aligned}
$$

\section{Analisis Model Regresi Data Panel tentang Angka Kematian Bayi (AKB) di Jawa Timur.}

Analisis model dilakukan dengan menjalankan uji statistik untuk mengetahui bermakna atau tidaknya variabel atau model yang digunakan secara parsial maupun keseluruhan. Uji statistik yang dilakukan antara lain:

\section{Uji t statistik (Parsial)}

Pengujian secara parsial atau masing-masing variabel yang ada didalam model apakah signifikan secara statistik atau tidak dengan melihat nilai probabilitas dan $\alpha$. Penjelasan selengkapnya sebagai berikut:

a. Hasil uji t variabel PDRB perkapita menunjukkan nilai signifikan sebesar 0,001 dimana nilainya lebih kecil dari nilai alpha yang telah ditetapkan $(0,1)$, sehingga $\mathrm{H}_{0}$ ditolak dan $\mathrm{H}_{1}$ diterima yang berarti PDRB perkapita berpengaruh signifikan terhadap Angka Kematian Bayi (AKB).

b. Hasil uji t variabel rata-rata lama sekolah perempuan menunjukkan nilai signifikan sebesar 0,000 dimana nilainya lebih kecil dari nilai alpha yang telah ditetapkan $(0,1)$, sehingga $\mathrm{H}_{0}$ ditolak dan $\mathrm{H}_{1}$ diterima yang berarti rata-rata lama sekolah perempuan berpengaruh signifikan terhadap Angka Kematian Bayi (AKB).

c. Hasil uji t variabel lamanya pemberian ASI menunjukkan nilai signifikan sebesar 0.136 dimana nilainya lebih besar dari nilai alpha yang telah ditetapkan $(0,1)$, sehingga $\mathrm{H}_{0}$ diterima dan $\mathrm{H}_{1}$ ditolak yang berarti lamanya pemberian ASI tidak berpengaruh signifikan terhadap Angka Kematian Bayi (AKB).

d. Hasil uji t variabel waktu tempuh ke fasilitas layanan kesehatan, menunjukkan nilai signifikan sebesar 0,000 dimana nilainya lebih kecil dari nilai alpha yang telah ditetapkan $(0,1)$, sehingga $\mathrm{H}_{0}$ ditolak dan $\mathrm{H}_{1}$ diterima yang berarti waktu tempuh ke fasilitas layanan kesehatan, berpengaruh signifikan terhadap Angka Kematian Bayi (AKB).

e. Hasil uji $\mathrm{t}$ variabel jumlah posyandu menunjukkan nilai signifikan sebesar 0,011 dimana nilainya lebih kecil dari nilai alpha yang telah ditetapkan $(0,1)$, sehingga $\mathrm{H}_{0}$ ditolak dan $\mathrm{H}_{1}$ diterima yang berarti jumlah posyandu berpengaruh signifikan terhadap Angka Kematian Bayi (AKB).

f. Hasil uji t variabel jumlah tenaga medis menunjukkan nilai signifikan sebesar 0.884 dimana nilainya lebih besar dari nilai alpha yang telah ditetapkan $(0,1)$, sehingga $\mathrm{H}_{0}$ diterima dan $\mathrm{H}_{1}$ ditolak yang berarti jumlah tenaga medis tidak berpengaruh signifikan terhadap Angka Kematian Bayi (AKB).

g. Hasil uji t variabel jumlah paramedis menunjukkan nilai signifikan sebesar 0,000 dimana nilainya lebih kecil dari nilai alpha yang telah ditetapkan $(0,1)$, sehingga $\mathrm{H}_{0}$ ditolak dan $\mathrm{H}_{1}$ diterima yang berarti jumlah paramedis berpengaruh signifikan terhadap Angka Kematian Bayi (AKB).

h. Hasil uji t variabel cakupan imunisasi menunjukkan nilai signifikan sebesar 0,016 dimana nilainya lebih kecil dari nilai alpha yang telah ditetapkan $(0,1)$, sehingga $\mathrm{H}_{0}$ ditolak dan $\mathrm{H}_{1}$ diterima yang berarti cakupan imunisasi berpengaruh signifikan terhadap Angka Kematian Bayi (AKB). 


\section{EKONOMIKAWAN : Jurnal Ilmu Ekonomi dan Studi Pembangunan}

I55N : $1693-7600$ (print), 155N : 2598-0157 (Online), hutp://fumal_umstiacid//index.php/ekawan

Berikut akan dilakukan interprestasi besaran koefisien hasil regresi data panel sebagai berikut:

a. Variabel PDRB perkapita sebesar $-0,00009$

Kabupaten kota yang mampu meningkatkan PDRB perkapita sebesar satu jutaan rupiah, maka akan menurunkan Angka Kematian Bayi (AKB) sebesar 0,00009 per 1000 kelahiran hidup, dengan asumsi variabel bebas lainnya dianggap konstan (cateris paribus).

b. Variabel rata-rata lama sekolah perempuan sebesar $-2,49$

Peningkatan rata-rata lama sekolah di Kabupaten kota selama 1 tahun akan menurunkan Angka Kematian Bayi (AKB) di Kabupaten Kota sebesar 2,4 poin, dengan asumsi variabel lain adalah konstan (cateris paribus).

c. Variabel lamanya pemberian ASI sebesar $-0,26$

Peningkatan lamanya pemberian ASI selama 1 bulan akan menurunkan Angka Kematian Bayi (AKB) di Kabupaten Kota sebesar 0,26 poin, dengan asumsi variabel lain adalah konstan (cateris paribus). Walaupun secara parsial, variabel lamanya pemberian ASI tidak signifikan berpengaruh menurunkan Angka Kematian Bayi.

d. Variabel waktu tempuh ke fasilitas layanan kesehatan, sebesar 0,1

Variabel ini menjelaskan presentase rumah tangga yang waktu tempuhnya 30 menit ke fasilitas pelayanan kesehatan. Sehingga, Peningkatan persentase rumah tangga yang waktu tempuhnya 30 menit ke fasilitas pelayanan sebesar 1 persen akan meningkatkan Angka Kematian Bayi (AKB) di Kabupaten Kota sebesar 14 persen, dengan asumsi variabel lain adalah konstan (cateris paribus).

e. Variabel jumlah posyandu sebesar $-0,019$

Peningkatan jumlah posyandu sebesar 1,9 persen akan menurunkan Angka Kematian Bayi (AKB) di Kabupaten Kota sebesar 1,9 persen, dengan asumsi variabel lain adalah konstan (cateris paribus).

f. Variabel jumlah tenaga medis sebesar $-9,47$.

Peningkatan jumlah Tenaga medis sebesar 9 tenaga medis akan menurunkan Angka Kematian Bayi (AKB) di kabupaten kota sebesar 1 poin AKB per 1.000 kelahiran hidup, dengan asumsi variabel lain adalah konstan (cateris paribus). Walaupun secara parsial, variabel jumlah tenaga medis tidak signifikan berpengaruh menurunkan Angka Kematian Bayi.

g. Variabel jumlah paramedis sebesar $-56,3$

Peningkatan sebesar 56 tenaga paramedis akan menurunkan Angka Kematian Bayi (AKB) di kabupaten kota sebesar 1 poin AKB per 1.000 kelahiran hidup, dengan asumsi variabel lain adalah konstan (cateris paribus).

h. Variabel cakupan imunisasi sebesar $-0,016$

Peningkatan cakupan imunisasi sebesar 1,6 persen akan menurunkan Angka Kematian Bayi (AKB) di kabupaten kota sebesar 1,6 persen, dengan asumsi variabel lain adalah konstan (cateris paribus).

\section{Uji $\boldsymbol{F}$-statistik (simultan)}

Hasil uji F-variabel penelitian ini menunjukkan nilai signifikan sebesar 0,000. Hal ini berarti secara keseluruhan variabel independen (PDRB perkapita, rata-rata lama sekolah perempuan, lama pemberian ASI, waktu tempuh ke fasilitas layanan kesehatan, jumlah posyandu, jumlah tenaga medis, tenaga paramedis, dan cakupan imunisasi) secara bersama-sama berpengaruh terhadap Angka Kematian Bayi (AKB). 
$\mathbf{U j i}^{\mathbf{2}}$

Hasil uji R-Squared penelitian ini menunjukkan nilai sebesar 0.985305. Berarti kemampuan variabel independen dalam menjelaskan varians dari variabel dependen adalah sebesar 98 persen, dan terdapat 2 persen varians variabel dependen yang dijelaskan oleh faktor lain.

\section{Analisis dan Pembahasan Angka Kematian Bayi di Jawa Timur}

Analisis dan pembahasan akan dihubungkan antara hasil regresi data panel dengan teori dan penelitian sebelumnya. Apabila tidak sesuai akan dijelaskan penyebab Angka Kematian Bayi (AKB) di Jawa Timur, penjelasannya sebagai berikut:

\section{a. Pengaruh PDRB perkapita terhadap Angka Kematian Bayi (AKB) di Jawa Timur.}

Hasil regresi data panel menunjukkan bahwa variabel PDRB perkapita secara signifikan mempengaruhi Angka Kematian Bayi di Jawa Timur. Kabupaten kota yang mampu meningkatkan PDRB perkapita sebesar satu jutaan rupiah, maka akan menurunkan AKB sebesar 0,00009 per 1000 kelahiran hidup, dengan asumsi variabel bebas lainnya dianggap konstan. Hasil dari penelitian ini sejalan dengan beberapa penelitian sebelumnya, yaitu Warsita dan Marhaeni (2015), Danawi dan Ogbonna (2014), Hulya dan Arik (2009), Nishiyama (2011), Goza et al (2004), Rodgers (2002), Dallolio et al (2012), Kurniawati (2015), Barbus (2011), Flegg (1982), Rezaei et al (2015), dan Sadetskaya (2015). Beberapa peneliti tersebut berpendapat bahwa PDRB perkapita yang lebih tinggi merupakan prasyarat untuk mendapatkan lingkungan dan makanan yang lebih sehat, serta pelayanan kesehatan yang lebih baik. Ibu yang memiliki pendapatan yang tinggi akan memilih pelayanan kesehatan yang baik demi mengurangi resiko kematian bayi.

Oleh karena itu, dalam upaya menurunkan Angka Kematian Bayi (AKB) akan tercapai jika pemerintah memfokuskan perhatian pada program pengurangan ketimpangan dan menambah infrastruktur sosial. Penelitian Bappernas (2009) menyatakan hal demikian, kebijakan pemerintah lebih banyak mempengaruhi dalam menentukan penurunan Angka Kematian Bayi melalui program pembangunan daerah untuk mengurangi ketimpangan dan pembangunan infrastruktur.

Beberapa kabupaten kota di Jawa Timur yang PDRB perkapitanya terendah perlu mendapatkan perhatian dikarenakan AKB-nya juga termasuk dalam kabupaten kota dengan AKB masih tinggi. Gambar 4 memperlihatkan diagram tebar (scatterplot) dari kabupaten kota di Provinsi Jawa Timur, dimana terlihat kabupaten kota yang PDRBnya rendah, akan bersanding dengan AKB yang tinggi. Beberapa kabupaten kota tersebut adalah Kabupaten Probolinggo, Kabupaten Jember, Kabupaten Bangkalan, Kabupaten Situbondo, Kabupaten Bondowoso, Kabupaten Pasuruan, Kabupaten Sumenep, Kabupaten Pamekasan, Kabupaten Bojonegoro, Kota Pasuruan, Kabupaten Lumajang Kabupaten Lamongan. 


\section{EKONOMIKAWAN : Jurnal Ilmu Ekonomi dan Studi Pembangunan}

I55N : 1693-7600 (print), 155N : 2598-0157 (Online), hutp://rumal.umstiacid//index,php/ekawan

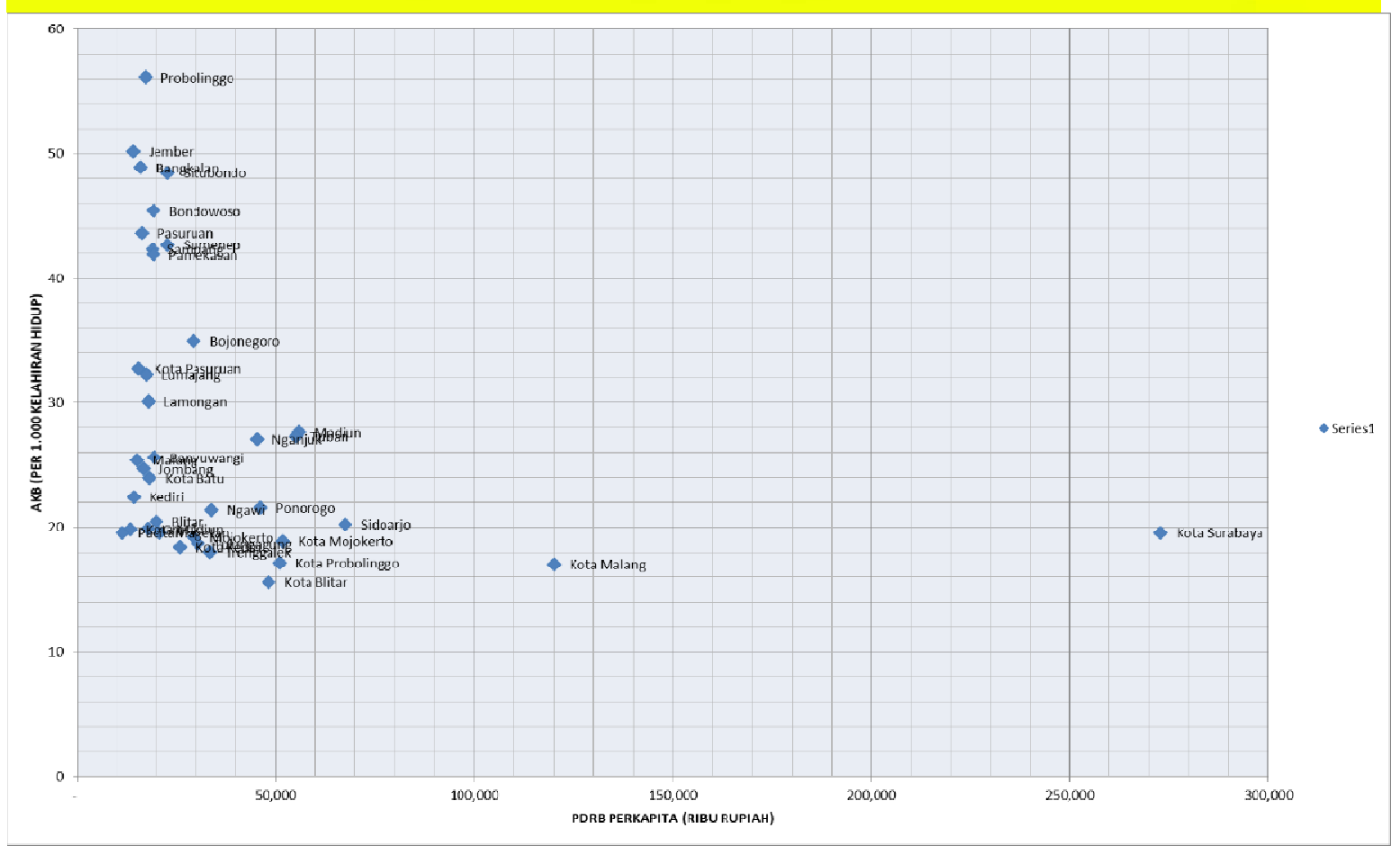

Gambar 4. Scatterplot AKB dan PDRB Perkapita di Provinsi Jawa Timur, 2016

\section{b. Pengaruh rata-rata lama sekolah perempuan terhadap Angka Kematian Bayi (AKB) di Jawa Timur.}

Hasil regresi data panel menunjukkan bahwa variabel rata-rata lama sekolah perempuan secara statistik signifikan mempengaruhi Angka Kematian Bayi (AKB) di Jawa Timur. Peningkatan rata-rata lama sekolah perempuan selama satu tahun, maka akan mengakibatkan penurunan pada Angka Kematian Bayi (AKB) sebesar 2,4 per 1.000 kelahiran hidup. Hasil penelitian ini sejalan dengan beberapa penelitian tersebut antara lain, Warsita dan Marhaeni (2015), Iram dan Butt (2008), dan Breiman (2004), bahwa ratarata lama sekolah pada perempuan mempengaruhi angka kematian bayi.

Rata-rata lama sekolah dapat diartikan sebagai kualitas pendidikan dari kabupaten kota di Jawa Timur. Semakin tinggi pendidikan orang tua, terutama dari ibu, semakin banyak pengetahuan, wawasan dan keterampilan yang gunakan untuk merawat bayi mereka. Bayi yang memiliki ibu dengan pendidikan yang tinggi, memiliki resiko kematian bayi yang rendah. Semakin tinggi tingkat pendidikan ibu, ibu memiliki lebih banyak Informasi kesehatan yang dibutuhkan janin, sehingga mengurangi resiko kematian Bayi. Ketimpangan kualitas pendidikan di Jawa Timur sangat menentukan kualitas kesehatan dan pada akhirnya akan mempengaruhi Angka Kematian Bayi di Jawa Timur. Selain masalah ketimpangan, pendidikan perempuan di Jawa Timur masih terkendala faktor budaya. Para pendukung teori stratifikasi gender memusatkan perhatian pada disparitas dalam hak istimewa antara laki-laki dan perempuan dan perbaikan dalam status perempuan dianggap mengurangi kematian anak (bayi) karena akses perempuan terhadap pekerjaan, pendidikan, gizi, dan perawatan kesehatan yang meningkat.

Peningkatan pendidikan perempuan merupakan salah satu cara yang paling penting untuk mengurangi angka kematian anak (bayi). Ibu yang berpendidikan lebih cenderung mencari perawatan kesehatan terbaik untuk anak (bayi) mereka. Seorang ibu terpelajar lebih mungkin untuk dapat berkomunikasi dengan penyedia layanan kesehatan dan pendidikan perempuan memiliki efek positif pada pengasuhan anak (bayi). Namun, streo 


\section{Published, Volume 20 No. 1, Juli 2020 \\ EKONOMIKAWAN : Jurnal Ilmu Ekonomi dan Studi Pembangunan \\ I55N : $1693-7600$ (print), 155N : 2598-0157 (Online), hutp:/humal.umsu.acid//index,php/ekawan}

tipe gender yang mengakar kuat dalam budaya patriaki Indonesia memaksa sebagian kaum perempuan untuk mundur dari menuntut pendidikan setinggi-tingginya. Seharusnya pendidikan tinggi tidak lagi memandang gender. Laki-laki maupun perempuan sama-sama berhak mendapatkan pendidikan tinggi. Stigma bahwa perempuan kelak akan menjadi ibu rumah tangga telah mengukung pikiran masyarakat, sehingga pendidikan tinggi bagi kaum perempuan menjadi sesuatu yang tidak mudah untuk dicapai.

Terkait dengan masalah pendidikan, khususnya pada pendidikan perempuan, wilayah pandalungan dan wilayah Madura perlu mendapat perhatian yang lebih dari pemerintah. Terlihat di Gambar 4.19, Beberapa kabupaten tersebut selain rata-rata lama sekolahnya paling rendah juga Angka Kematian Bayi (AKB) juga termasuk dalam Kabupaten kota dengan AKB tertinggi, yaitu Kabupaten Sampang, Kabupaten Sumenep, Kabupaten Bangkalan, Kabupaten Bondowoso, Kabupaten Probolinggo, Kabupaten Pamekasan, Kabupaten Kabupaten Situbondo, Kabupaten Jember, Kabupaten Pasuruan dan Kabupaten Lumajang.

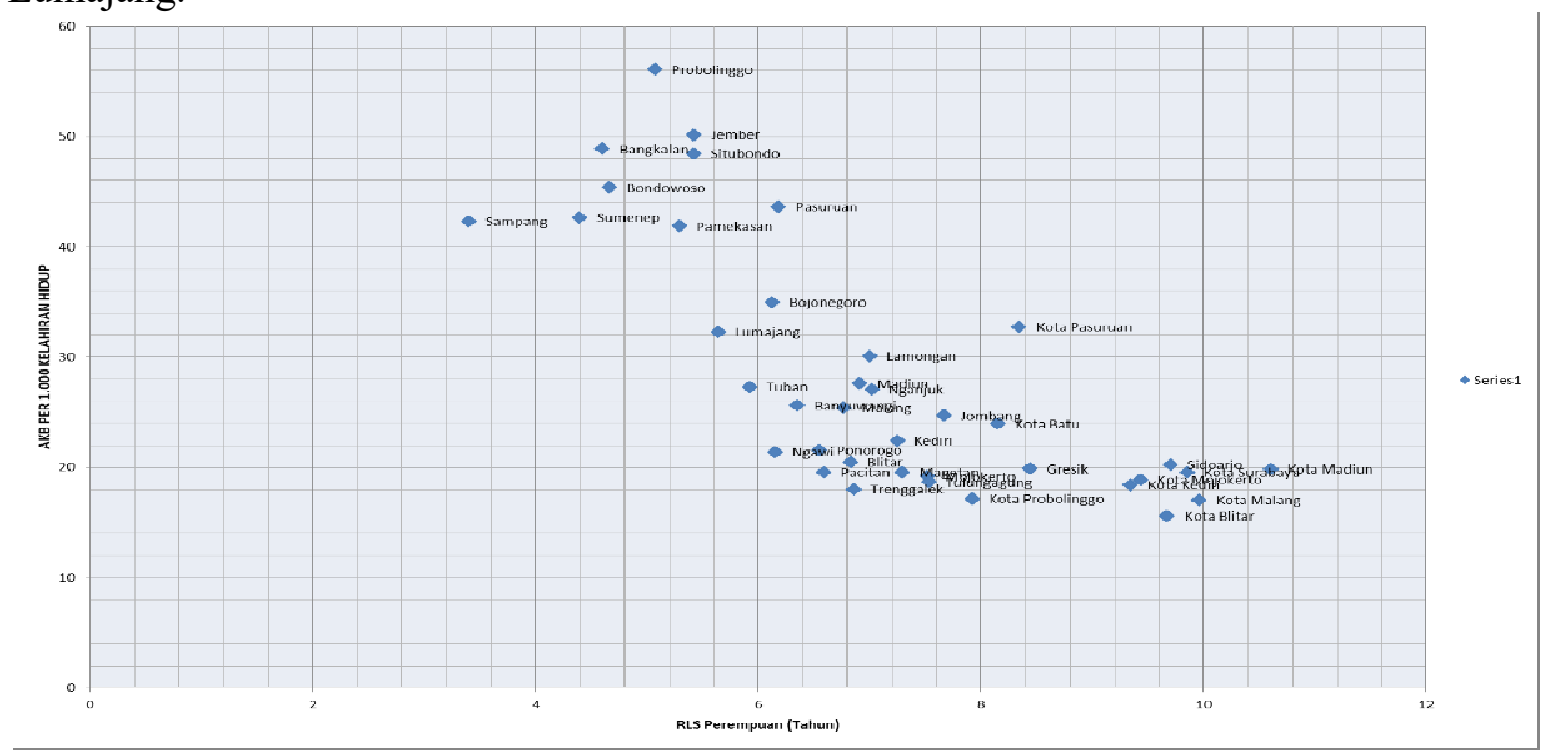

Gambar 5. Scatterplot AKB dan Rata-rata Lama Sekolah Perempuan di Provinsi Jawa Timur, 2016

\section{c. Pengaruh lama pemberian ASI terhadap Angka Kematian Bayi (AKB) di Jawa Timur.}

Hasil regresi data panel menunjukkan bahwa variabel lama pemberian ASI secara statistik parsial tidak signifikan mempengaruhi Angka Kematian Bayi (AKB) di Jawa Timur. Hasil penelitian ini berbeda dengan beberapa penelitian sebelumnya antara lain, Iram dan Butt (2008) dan Abdiana (2015), dimana berkesimpulan bahwa perilaku pemberian ASI eksklusif berpengaruh signifikan negatif terhadap Angka Kematian Bayi di suatu wilayah, atau semakin lama rata-rata pemberian ASI semakin rendah Angka Kematian Bayi.

Pemberian ASI Eklusif dipandang sebagai imunisasi alami. Studi kesehatan berpendapat bahwa pemberian ASI Eklusif akan menurunkan resiko kematian bayi karena infeksi. Selain itu, beberapa studi kesehaan menyebutkan pemberian ASI mencegah berat bayi lahir rendah (BBLR) dan stuning, serta menurunkan risiko obesitas dan penyaki kronis. Walaupun secara parsial pemberian ASI tidak berpengaruh signifikan, namun secara simultan pemberian ASI tetap berpengaruh signifikan terhadap AKB di Jawa Timur, Oleh sebab itu, pemerintah harus tetap memberikan fokus perhatian, baik dari sisi preventif 
melalui sosialisasi pemberian ASI eksklusif, maupun insentif ibu menyusui dengan memberikan waktu dan ruangan khusus laktasi. Hal ini dirasa penting karena kendala pekerja wanita tidak menyusui bayinya, dikarenakan tidak tersedia waktu luang dan tempat untuk laktasi.

\section{d. Pengaruh waktu tempuh ke fasilitas pelayanan kesehatan terhadap Angka Kematian Bayi (AKB) di Jawa Timur.}

Hasil regresi data panel menunjukkan bahwa variabel waktu tempuh ke fasilitas pelayanan kesehatan signifikan mempengaruhi Angka Kematian Bayi (AKB) di Jawa Timur. Peningkatan variabel ini sebesar 1 persen akan meningkatkan Angka Kematian Bayi (AKB) di Jawa Timur sebesar 0,14 poin per kelahiran hidup.

Upaya pemerintah dalam menurunkan AKB di Jawa Timur dilakukan tidak hanya menambah fasilitas kesehatan, namun diperlukan faktor pemerataan, sehingga jarak tempuh masyarakat ke fasilitas kesehatan lebih terjangkau. Penelitian ini sejalan dengan penelitian yang dilakukan oleh Pramono (2012), dimana faktor jarak ke fasilitas kesehatan juga mempengaruhi angka kematian bayi, selain faktor infrastruktur pelayanan kesehatan dan penyediaan jumlah tempat tidur rumah sakit mempengaruhi angka kematian bayi, pada penelitian Vaidean dan Pipas (2015).

Selain itu, pemerintah diperlukan membangun pemukiman yang sehat dalam upaya menurunkan AKB. Pemukiman dengan sanitasi baik, bersih dan jarak ke fasilias kesehatan dekat. Pemukiman padat menciptakan akumulasi kerugian sosial ekonomi terhadap angka kematian bayi. Penelitian Rosicova et al (2011) dan Penelitian Sadetskaya (2015) menyatakan bahwa peningkatan kepadatan perumahan menciptakan kondisi yang tidak menguntungkan untuk peluang kelangsungan hidup bayi.

\section{e. Pengaruh jumlah posyandu, jumlah tenaga medis, dan jumlah tenaga paramedis terhadap Angka Kematian Bayi (AKB) di Jawa Timur.}

Hasil regresi data panel menunjukkan bahwa variabel jumlah posyandu, jumlah tenaga medis, jumlah tenaga paramedis secara simultan signifikan mempengaruhi Angka Kematian Bayi (AKB) di Jawa Timur, namun secara parsial hanya jumlah tenaga medis yang tidak signifikan mempengaruhi Angka Kematian Bayi (AKB) di Jawa Timur. Hasil estimasi menyatakan kabupaten kota yang mampu meningkatkan jumlah posyandu sebesar 1,9 persen akan menurunkan Angka Kematian Bayi (AKB) di Kabupaten Kota sebesar 1,9 persen, dan kabupaten kota yang mampu meningkatkan jumlah tenaga paramedis sebesar 56 tenaga paramedis akan menurunkan Angka Kematian Bayi (AKB) sebesar 1 poin per kelahiran hidup.

Hasil penelitian ini sedikit berbeda dengan penelitian Bappenas (2009), dimana menghasilkan kesimpulan bahwa faktor kebijakan pemerintah atau faktor penawaran menurut teori Filmer lebih banyak mempengaruhi dalam menentukan kelangsungan hidup bayi. Peran pemerintah dalam menyediahkan layanan kesehatan meliputi jumlah dokter, jumlah tenaga kesehatan, jumlah posyandu. Selain itu, penelitian Nguyen et al (2016) dan Penelitian Anand (2004) berkesimpulan bahawa penyediaan tenaga medis dan tenaga paramedis mempengaruhi penurunan angka kematian bayi

\section{f. Pengaruh cakupan imunisasi terhadap Angka Kematian Bayi (AKB) di Jawa Timur.}

Hasil regresi data panel menunjukkan bahwa variabel cakupan imunisasi secara statistik signifikan mempengaruhi Angka Kematian Bayi (AKB) di Jawa Timur. Hasil 
estimasi model menyatakan bahwa peningkatan persentase cakupan imunisasi di desa/kelurahan Jawa Timur sebesar satu persen akan menurunkan Angka Kematian Bayi (AKB) sebesar 1,6 persen. Hasil penelitian ini sejalan dengan penelitian Vaidean dan Pipas (2015), dan Penelitian Rezaei et al (2015) dimana menyatakan peran pemerintah dalam sektor kesehatan dan penyediaan imunisasi lengkap menentukan angka kematian bayi, memiliki efek negatif dan signifikan.

Penyebab kematian bayi terbanyak disebabkan oleh masalah neonatal seperti Asfiksia, Diare, berat bayi lahir rendah (BBLR), dan Pneumonia, dimana penyakit tersebut dapat dicegah dengan Imunisasi. Oleh karenanya, mengingat peran pentingnya imunisasi, pemerintah berkewajiban menyediahkan imunisasi murah dan efektif, serta memperluas cakupan imunisasi desa/kelurahan. Namun, terdapat Suatu tantangan yang dihadapi dalam upaya meningkatkan cakupan imunisasi, menurut data riset kesehatan dasar (Riskesdas) 2013 menyebutkan beberapa alasan anak tidak diimunisasi antara lain keluarga tidak mengizinkan, karena takut anaknya panas, jarak tempat imunisasi jauh, dan tidak tahu tempat imunisasi, serta kesibukan orang tua.

\section{g. Implikasi Kebijakan Pemerintah Dalam Menurunkan Angka Kematian Bayi di Jawa Timur}

Sesuai dengan amanah UUD 1945, pada hakekatnya tujuan program pemerinah adalah menciptakan kesejahteraan bagi masyarakat. Kesejahteraan diraih dengan adanya pembangunan, salah satunya pembangunan kesehatan.

Pembangunan kesehatan adalah salah satu bagian dari pembangunan nasional. Masyarakat yang memiliki tingkat kesehatan yang baik, maka produktifitas akan meningkat. Presiden Joko Widodo pernah menyampaikan pidato bertajuk "visi Indonesia", dimana pada pidato tersebut presiden menyiapkan tahapan-tahapan besar pembangunan. Pada pidato tersebut presiden menempatkan pembangunan infrastruktur di posisi pertama dan pembangunan sumber daya manusia di posisi kedua. Hal ini merupakan suatu hal yang positif dalam menurunkan Angka Kematian Bayi di Indonesia dan khususnya di Provinsi Jawa Timur. Pakar Developmental State Theory berpendapat bahwa pemerintah adalah aktor penting dalam ekonomi nasional.

Berdasarkan fakta empiris dari penelitian ini, beberapa implikasi kebijakan yang perlu dilakukan pemerintah daerah Kabupaten kota dan provinsi Jawa Timur antara lain:

1. Menjalankan amanat Undang-Undang nomor 36 Tahun 2009 tentang Kesehatan, dimana besar anggaran kesehatan pemerintah daerah provinsi, kabupaten kota dialokasikan minimal 10 persen dari anggaran pendapatan dan belanja daerah di luar gaji. Anggaran tersebut dapat diprioritaskan untuk mendukung program Jaminan Kesehatan Nasional (JKN), sehingga dapat mengurangi masalah ketimpangan pendapatan. Dan menjalankan amanat undang-undang tentang besaran anggaran pendidikan 20 persen, tertuang di UUD 1945 pasal 31 ayat 4 dan UU Sistem Pendidikan Nasional Nomor 20 tahun 2003 pasal 49 ayat 1.

2. Peningkatan pendapatan masyarakat melalui program pemberdayaan perekonomian masyarakat, dan pemerataan pembangunan di kabupaten kota di Provinsi Jawa Timur.

3. Peningkatan derajat kesehatan dan status gizi terutama bagi penduduk miskin dan kelompok rentan.

4. Peningkatan kuantitas, pemerataan, keterjangkauan, dan kualitas pelayanan kesehatan di fasilitas pelayanan kesehatan.

5. Peningkatan kualitas dan kuantitas tenaga kesehatan terutama untuk pelayanan kesehatan di kabupaten kota di Provinsi Jawa Timur. 


\section{EKONOMIKAWAN : Jurnal Ilmu Ekonomi dan Studi Pembangunan}

I55N : $1693-7600$ (Print), 155N : 2598-0157 (Online), hutp://fumal_umstiac.id//index.php/ekawan

6. Peningkatan sosialisasi kesehatan dan pemberdayaan masyarakat dalam perilaku hidup bersih dan sehat.

\section{SIMPULAN}

Dilihat dari hasil penelitian dan pembahasan pada penelitian ini menghasilkan kesimpulan PDRB perkapita, rata-rata lama sekolah pada perempuan, lamanya pemberian ASI, waktu tempuh ke fasilitas layanan kesehatan, jumlah layanan posyandu, jumlah tenaga medis, jumlah tenaga paramedis, dan cakupan imunisasi secara simultan berpengaruh terhadap angka kematian bayi di Provinsi Jawa Timur. Namun Secara parsial, hanya variabel PDRB Perkapita, rata-rata lama sekolah perempuan, waktu tempuh ke fasilitas layanan kesehatan, Jumlah layanan posyandu, variabel tenaga paramedis dan cakupan imunisasi yang berpengaruh terhadap Angka Kematian Bayi di Provinsi Jawa Timur.

\section{DAFTAR PUSTAKA}

Anand, Sudhir and Barnighausen Till. (2004). Human resources and Health Outcomes:Cross-Country Econometric Study. The Lancet, Oct 30 - Nov 5.

Arik, Hulya \& Murat Arik. (2009). Is It Economic Growth or Socioeconomic Development? A Cross Sectional Analysis of The Determinants of Infant Mortality. The ba of Developing Areas; Nashville, Vol 42.

Abdiana. (2015). Determinan Kematian Bayi di Kota Payakumbuh. Jurnal Kesehatan Masyarakat Andalas. September. Vol 9, No.2, Hal 88-92.

Badan Penelitian dan Pengembangan Kesehatan Departemen Kesehatan RI. (2007). Laporan Hasil Riset Kesehatan Dasar (RISKESDAS) 2007. Provinsi Jawa Timur.

Badan Penelitian dan Pengembangan Kesehatan Kementerian Kesehatan RI. (2013). Riset Kesehatan Dasar Dalam Angka, RISKESDAS 2013. Provinsi Jawa Timur.

Barufi, Ana Maria, Eduardo Haddad and Antonio Paez. (2012). Infant Mortality in Brazil, 1980-2000: A Spatial Panel Data Analysis. BMC Public Health, 12:181.

Blanchard, Oliver and David R. Johnson. (2013). Macroeconomics. Sixth Edition. Pearson

BPS (Badan Pusat Statistik). Data diakses melalui website : www.bps.go.id

BPS Provinsi Jawa Timur. Data diakses melalui Website: www.jatim.bps.go.id

Breiman, Robert F, Peter Kim Streatfield, Maureen Phelan, Naima Shifa, Mamunur Rashid, Mohammed Yunus. (2004). Effect of Infant Imunisation on Childhood Mortality in Rural Bangladesh: Analysis of Health and Demographic Surveillance Data. Lancet. Vol. 364, December 18/25: 2204 - 2211

Dinas Kesehatan Provinsi Jawa Timur. (2011). Profil Kesehatan Provinsi Jawa Timur Tahun 2010. Data diakses melalui website : dinkes.jatimprov.go.id

Dinas Kesehatan Provinsi Jawa Timur. (2012). Profil Kesehatan Provinsi Jawa Timur Tahun 2011. Data diakses melalui website : dinkes.jatimprov.go.id

Dinas Kesehatan Provinsi Jawa Timur. (2013). Profil Kesehatan Provinsi Jawa Timur Tahun 2012. Data diakses melalui website : dinkes.jatimprov.go.id

Dinas Kesehatan Provinsi Jawa Timur. (2014). Profil Kesehatan Provinsi Jawa Timur Tahun 2013. Data diakses melalui website : dinkes.jatimprov.go.id

Dinas Kesehatan Provinsi Jawa Timur. (2015). Profil Kesehatan Provinsi Jawa Timur Tahun 2014. Data diakses melalui website : dinkes.jatimprov.go.id

Dinas Kesehatan Provinsi Jawa Timur. (2016). Profil Kesehatan Provinsi Jawa Timur Tahun 2015. Data diakses melalui website : dinkes.jatimprov.go.id 
Dinas Kesehatan Provinsi Jawa Timur. (2017). Profil Kesehatan Provinsi Jawa Timur Tahun 2016. Data diakses melalui website : dinkes.jatimprov.go.id

Fantini MP, Stivanello E, Dallolio L, Loghi M. (2006). Persistent geographical disparities in infant mortality rates in Italy (1999-2001): comparison with France, England, Germany, and Portugal. Eur J Public Health 16:429-432.

Filmer, Deon. (2003). Determinants of Health and Education Outcomes. Background Note for World Development Report 2004: Making Service Work for Poor People. The World Bank.

Flegg, A. T. (1982). Inequality of Income, Illiteracy and Medical Care as Determinants of Infant Mortality in Underdeveloped Countries. Population Studies, Vol 36, No.3 (Nov.,1982), Pp.441-458.

Goza, Franklin W, Edward G Stockwell, Kelly S Balisteri. (2004). The Relationship Between Socioeconomic Status dan Infant Mortality in Metropolitan Ohio, 19992001. Social Biology. New York. Vol 51. Pp:83-93.

Iram, Uzma and Muhammad S. Butt. (2008). Socioeconomic Determinants of Child Mortality in Pakistan, Evidence from Sequential Probit Model. International Journal of Social Economics, Vol. 35, No $1 / 2$.

Jain, A.K. (1985). Determinants of Regional Variations in Infant Mortality in Rural India. Population Studies 39, Pp:407-424.

Khadka, Khim Bahadur, Leslie Sue L., Vincentas Giedraitis, Laxmi Bhatta and Ganesh Pandey. (2015). BMC Pediatrics. 15: 152.

Kumar Abhishek and Abhishek Singh. (2014). Is Economic Inequality in Infant Mortality Higher in urban than in Rural India?. Matern Child Health J, 18: 2061-2070.

Kurniawati, Sisvia Cahya. (2015). Pemodelan Jumlah Kematian Bayi di Jawa Timur dengan Geographically Weighted Poisson Regression (GWPR). GEOID, Vol 10, No. 02, Februari. Pp:187-193.

Mosley, W. Henry. \& Chen, Lincoln. C. (1984). An Analytical Framework for the Study of Child Survival in Developing Countries. Population and Development Review, Vol. 10, Supplement: Child Survival: Strategies For Research.

Nguyen, Phuong Mai, Tolib Mirzoev and Thi Minh Le. (2016). Contribution of health Workforce to Health Outcomes: Empirical Evidence from Vietnam. Human Resources for Health. $14-68$.

Nishiyama, Akira. 2011. Economic Growth and Infant Mortality in Developing Countries. European Journal of Development Research. Vol. 23, 4, 630-647

Pramono, Mochamad Setyo, Suci Wulandari dan Sutikno. (2012). Pemetaan Determinan Angka Kematian Bayi di Jawa Timur Berdasarkan Indikator Indeks Pembangunan Kesehatan Masyarakat. Buletin Penelitian Sistem Kesehatan. Vol 15. No 1. Pp:38-46

Reidpath DD, \& Allotey P. (2003). Infant mortality rate as an indicator of population health. J Epidemiol Community Health 57:344-346.

Rezaei, Satar, Khalil Moradi, Behzad Karami Matin. (2015). Macro Determinants of Infant Mortality in ECO Countries: Evidence from Panel Data Analysis. Int J Pediatr, Vol.3, N.1-2, Serial No 14, February 2015.

Rezaei, Satar, Behzad Karami Matin. Enayatollah Homaie Rad. (2015). Socioeconomic Determinants of Infant Mortality in Iranian Children: A Longitudinal Econometrics Analysis. Int J Pediatr, Vol.3, N.1-1, Serial No 13, January 2015.

Rodgers,G.B. (2002). Income and Inequality as determinants of mortality: an International cross-section analysis. International Journal of Epidemioology, Volume 31, Issue 3, 1 June 2002, Pages 533-538. 


\section{EKONOMIKAWAN : Jurnal Ilmu Ekonomi dan Studi Pembangunan}

I55N : $1693-7600$ (Print), $155 N$ : $2598-0157$ (Online), http://Jumalumstiac.id/index.php/ekawan

Rostow, W. W. (1960). The Stages of Economic Growth. Cambridge University Press, New York.

Rosicova, Katarina, Andrea Madarasova Geckova, J. P. Van Dijk, Jana Kollarova, Martin Rosic \& Johan W Groothoff. (2011). Regional Socioeconomic Indicators and Ethnicity as Predictors of Regional Infant Mortality Rate in Slovakia. Int J Public Health, 56:523-531.

Sadetskaya, Katerina. (2015). Infant Mortality Decline and Its Socioeconomic Correlates In New Zealand, 1873-1940. Australian Economic History Review, Vol. 55, No.2.

Warsita, Wika Mandala \& Marhaeni, A.A.I.N. 2015. Pengaruh PDRB Perkapita, Pendidikan Ibu, dan Pelayanan Kesehatan Terhadap Angka Kematian Bayi di Provinsi Bali. Piramida Vol. XI, No 1:35-40.

World Bank. Data diakses melalui website: http://databank.worldbank.org

Zatonski W, Mikucka M, La Vecchia C, Boyle P. 2006. Infant mortality in Central Europe: effects of transition. Gac Sanit 20:63-66. 